Original Research Article

\title{
Prescribing pattern of antimicrobials and adverse drug reactions in children suffering from lower respiratory tract infection in tertiary care hospital
}

\author{
Tarun Arora $^{1}$, Rudhra Prabhakar Kadali ${ }^{1}$, Rakhamaji D. Chandane ${ }^{1 *}$, Chandrapal Gautam ${ }^{2}$
}

${ }^{1}$ Department of Pharmacology, Lady Hardinge Medical College, New Delhi, India

${ }^{2}$ Department of Pharmacology, University College of Medical Sciences and Guru Teg Bahadur Hospital, Delhi, India

Received: 15 September 2018

Revised: 01 October 2018

Accepted: 08 October 2018

*Correspondence to: Dr. Rakhamaji D. Chandane, Email: drchandanerd@ rediffmail.com

Copyright: (C) the author(s), publisher and licensee Medip Academy. This is an openaccess article distributed under the terms of the Creative Commons Attribution NonCommercial License, which permits unrestricted noncommercial use, distribution, and reproduction in any medium, provided the original work is properly cited.

\begin{abstract}
Background: Acute respiratory tract infections are leading cause of mortality in children in India. Further, indiscriminate use of antimicrobials has led to increased drug resistance and large number of adverse drug reactions (ADR). Therefore, aim of study was to study antimicrobial prescribing pattern and record incidence and causality assessment of ADRs in pediatric in-patients having lower respiratory tract infection (LRTI).

Methods: In this prospective and observational study total of 300 children aged 2 months to 12 years suffering from LRTI and hospitalized for minimum $48 \mathrm{hrs}$ duration were included. A descriptive analysis was carried out to determine frequency and combinations of antibiotics prescribed and causality and number of ADRs.

Results: Out of 300 subjects, $70.3 \%$ of patients were males and $54.6 \%$ of cases with LRTI belonged to 2-6 months age group. The most frequently prescribed antibiotic was ceftriaxone alone in $67(22.3 \%)$ patients while ceftriaxone and amikacin was the most common 2 drug combination in $60(20 \%)$ patients. Ceftriaxone, ampicillin and gentamicin was most common 3 drug combination in $7(2.3 \%)$ patients. There were 49 cases $(16.3 \%)$ of ADRs and maximum were in 2-6 months age group and ceftriaxone with amikacin was associated with maximum number $10(20.4 \%)$ of cases. Diarrhoea was most frequent adverse effect associated with antibiotics in $36(76.6 \%)$ cases.

Conclusions: The use of cephalosporins (single or combination) are most commonly used drug and associated with maximum number of ADRs in 2-6 months male children with LRTI so clinicians should use them judiciously and rationally.
\end{abstract}

Keywords: Antimicrobials, Adverse drug reactions, Lower respiratory tract infection

\section{INTRODUCTION}

Acute respiratory tract infections (ARI) contribute to more than $75 \%$ of health care seeking in primary health care facilities. ${ }^{1}$ About $90 \%$ of ARI deaths are due to pneumonia, which is usually bacterial, pneumococcus being the commonest pathogen. ${ }^{2,3}$ Undernourished children, particularly the ones not exclusively breastfed or with inadequate zinc intake, are at a higher risk of developing pneumonia. ${ }^{4}$ Similarly, children and infants suffering from other illnesses, such as AIDS or measles, are more likely to develop pneumonia. Environmental factors, such as living in crowded homes and exposure to parental smoking or indoor air pollution also play a role in increasing child susceptibility to pneumonia and its severe consequences. $^{5}$ 
The most common LRTI are pneumonia, bronchitis and bronchiolitis. ${ }^{6}$ In India, recent epidemiological assessments in under-fives suggest that $13 \%$ of deaths and $24 \%$ of national burden of disease is due to pneumonia while hospital-based studies have reported $20 \%-30 \%$ of admissions in under-fives attributable to same cause. Case fatality rates of $8.7 \%-47 \%$ have been reported in hospitalized children. ${ }^{7,8}$ To help reduce mortality from these diseases, World Health Organization introduced case management guidelines based on simple clinical signs (fast breathing) for diagnosing pneumonia followed by empirical treatment with antibiotics. ${ }^{9}$

Chest X-rays and laboratory tests are used to confirm presence of LRTI, including extent and location of the infection and its cause. But in resource-poor settings without access to these technologies, suspected cases of LRTI are diagnosed by their clinical symptoms. Children and infants are presumed to have LRTI if they exhibit cough and fast or difficult breathing. ${ }^{10}$ Caregivers, therefore, have an important role to play in recognizing the symptoms of LRTI in children and seeking appropriate medical care as necessary. Antimicrobial agents are the commonly prescribed drugs for children. ${ }^{11}$ Because most cases of community acquired pneumonia are due to Haemophilus influenzae and Streptococcus pneumoniae, co-trimoxazole, penicillin, ampicillin, and amoxicillin have been recommended for control programmes. ${ }^{12}$

Most often, antibiotics are prescribed for diseases without laboratory confirmation of microbial etiology and in conditions where potential benefit of antibiotic therapy is uncertain (e.g. otitis media). ${ }^{13}$ Inappropriate antibiotic prescription in acute respiratory infections (ARI) is a major problem in developed countries. Evidence on the extent of problem in developing countries is still limited. ${ }^{14}$ Earlier studies have shown that use of broad-spectrum antibiotics increased from $10.6 \%$ to $40.6 \%$ for bronchitis in a span of 6 years from 1993 to $1999 .{ }^{15}$ and $85 \%$ of antibiotics prescribed for respiratory tract infection in children less than 5 years of age were inappropriate. ${ }^{1}$ In addition, indiscriminate use of antibiotics drives up the cost of health care, leads to plethora of side effects and drug interactions and fosters the emergence of bacterial resistance. $^{16}$

Adverse drug reactions (ADRs) are an important public health problem. A meta-analysis of 17 prospective studies performed in United States and Europe in 1973-2000 period estimated that the incidence of ADRs in hospitalized children is $9.53 \%$ and in pediatric outpatients $1.46 \% .{ }^{17}$ However data supporting prescribing pattern of antimicrobials and ADRs in pediatric population is limited in Indian set-up and based on outdated research, therefore this study was done to provide current evidence which may be helpful in introducing and implementing possible policies and interventions on improving antibiotics usage and decreasing /avoiding incidence of ADRs in developing countries like India.

\section{METHODS}

The study was conducted in Department of Pediatrics and Pharmacology, UCMS and GTB Hospital; Delhi. The study design was prospective and observational with a sample size of 300 children. All consecutive patients suffering from lower respiratory tract infection and admitted in pediatric ward, GTB Hospital were included. Clearance from institutional human ethics committee, written informed consent (from parent or caretaker of each subject before participation in study) and care of each subject was done as per declaration of Helsinki and guidelines on good clinical practice.

\section{Inclusion criteria}

- $\quad$ Age 2 months to 12 years, both sexes

- Hospitalized children in pediatric ward, who were prescribed antimicrobials for lower respiratory tract infection (diagnosed on clinical grounds and routine investigations, with or without radiological changes).

\section{Exclusion criteria}

- Patients with less than 48 hours hospitalization

- Reactions as a result of drug administration error, drug overdose or abuse and therapeutic failure, any guardian or caretaker unwilling to participate in the study.

\section{The following assessments were done during course of study}

- Patient characteristics such as age, sex, body weight, cases with previous drug history, duration of hospitalization were noted in an appropriately designed 'case record form' (CRF).

- Admission and discharge diagnosis, and condition of patient on admission and discharge were recorded in appropriately designed 'proforma for prescribing pattern'.

- Drug data, including name of drug, dosage regimen (form, route, frequency and duration), and the date on which pharmacotherapy was instituted was recorded in 'Proforma for prescribing pattern'.

- All patients were visited daily for ADRs in ward during hospitalization and followed up on day $7^{\text {th }}$ and day 14th after discharge in OPD or at home.

- When a suspected ADR was encountered, data of the drug and reaction were documented in a suitably designed ADR documentation form that included the drug name, dosage, route and frequency of consumption along with details of the ADR.

- ADRs were recorded and causality assessment was carried out as per WHO and Naranjo probability scale. ${ }^{18,19}$

- Subjects were divided into 3 age groups for comparative analysis i.e. 2 months- 6 months, $>6$ months to 2 years and $>2$ years- 12 years. A p value of less than 0.05 was taken for significance. 


\section{RESULTS}

In this study, number of male patients (211) was higher than female patients (89) (Table 1). Out of 300 patients, 164 patients belonged to 2 months- 6 months age group whereas 92 and 44 patients belonged to age groups $>6$ months- 2 years and $>2$ years- 12 years respectively (Table 1). From 300 patients of LRTI, 186 patients were diagnosed with pneumonia, 86 were diagnosed with wheeze associated lower respiratory tract infection (WALRTI), 15 had pleural effusion with consolidation, 7 were empyema and6 patients were post measles bronchopneumonia (Table 1, Table 2).

During hospitalization, 71 patients were prescribed 1 antibiotic, 212 patients were prescribed 2 antibiotics and 17 patients received prescription of 3 antibiotics (Table 3 ). In patients of 2 months- 6 months of age group, combination of ceftriaxone with amikacin was given to 54 patients which was highest in this age group.

Ceftriaxone alone was prescribed to 42 patients (Table 4) whereas in children of $>6$ months- 2 years of age group, 23 patients were prescribed a single antimicrobial agent which included ceftriaxone in 19 subjects and ampicillin in 4 subjects.

Table 1: Pediatric in-patient characteristics.

\begin{tabular}{|lll|}
\hline Parameter & No. of patients & Percentage \\
\hline Age & & \\
\hline 2 months-6 months & 164 & $54.6 \%$ \\
\hline$>6$ months-2 years & 92 & $30.6 \%$ \\
\hline >2years-12 years & 44 & $14.8 \%$ \\
\hline Sex & & \\
\hline Male & 211 & $70.3 \%$ \\
\hline Female & 89 & $29.7 \%$ \\
\hline Diagnosis & & $62 \%$ \\
\hline Pneumonia & 186 & $28.6 \%$ \\
\hline WALRTI & 86 & $5 \%$ \\
\hline $\begin{array}{l}\text { Pleural effusion } \\
\text { with consolidation }\end{array}$ & 15 & $2 \%$ \\
\hline Post-measles BPN & 06 & $2.4 \%$ \\
\hline Empyema & 07 & \\
\hline
\end{tabular}

a-Wheeze associated lower respiratory tract infection;

b-Bronchopneumonia

Table 2: Diagnostic pattern of LRTI in different age groups.

\begin{tabular}{|c|c|c|c|c|c|c|c|c|}
\hline \multirow{2}{*}{ Diagnosis } & \multicolumn{2}{|c|}{2 months - 6 months } & \multicolumn{2}{|c|}{$>6$ months - 2 years } & \multicolumn{2}{|c|}{$>2$ years- 12 years } & \multirow{2}{*}{$\begin{array}{l}\text { Total no. } \\
\text { of patients }\end{array}$} & \multirow{2}{*}{$\begin{array}{l}\% \text { of total } \\
\text { patients }\end{array}$} \\
\hline & No. of patients & $\%$ & No. of patients & $\%$ & No. of patients & $\%$ & & \\
\hline Pneumonia & 114 & 38 & 51 & 17 & 21 & 7 & 186 & 62 \\
\hline WALRTI $^{\mathrm{a}}$ & 48 & 16 & 32 & 10.6 & 06 & 2 & 86 & 28.6 \\
\hline $\begin{array}{l}\text { Pleural effusion } \\
\text { with consolidation }\end{array}$ & - & - & 05 & 1.6 & 10 & 3.3 & 15 & 5 \\
\hline Post-measles BPN ${ }^{b}$ & - & - & 04 & 1.3 & 02 & 0.6 & 06 & 2 \\
\hline Empyema & 02 & 0.6 & & & 05 & 1.6 & 07 & 2.3 \\
\hline
\end{tabular}

${ }^{\mathrm{a}}$ Wheeze associated lower respiratory tract infection; ${ }^{\mathrm{b}-B r o n c h o p n e u m o n i a}$

Table 3: Pediatric in-patient exposure to antibiotic(s).

\begin{tabular}{|lll|}
\hline Antibiotic(s)/patient & No. of patient & Percentage \\
\hline 1 & 71 & $23.7 \%$ \\
\hline 2 & 212 & $70.7 \%$ \\
\hline 3 & 17 & $5.6 \%$ \\
\hline
\end{tabular}

Most frequently prescribed combination of 2 antimicrobials was ampicillin with chloramphenicol (Table 5). In patients of $>2$ years- 12 years of age group, 6 patients were prescribed single antibiotic drug. Most frequently prescribed combination of 2 antimicrobial agents was ceftriaxone with cloxacillin (Table 6). Maximum average length of stay per underlying infection in hospital was 14.6 days seen in patients diagnosed with empyema while minimum average duration of stay per underlying infection was 5.2 days observed in patients with WALRTI. The overall average duration of hospital stay was 8.34 days (Table 7).
Table 4: Frequency of antibiotic /combination of antibiotics prescribed for LRTI in 2-6 months of age.

\begin{tabular}{|lll|}
\hline $\begin{array}{l}\text { Anti-microbial/combination of anti- } \\
\text { microbials }\end{array}$ & $\begin{array}{l}\text { No. of } \\
\text { patients }\end{array}$ & $\%$ \\
\hline Ceftriaxone & 42 & $25.6 \%$ \\
\hline Ceftriaxone and amikacin & 54 & $32.9 \%$ \\
\hline Ampicillin and gentamicin & 24 & $14.6 \%$ \\
\hline Ceftriaxone and cloxacillin & 13 & $7.9 \%$ \\
\hline Ampicillin and chloramphenicol & 09 & $5.4 \%$ \\
\hline Ampicillin and chloromycetin & 06 & $3.6 \%$ \\
\hline Ceftriaxone and vancomycin & 04 & $2.4 \%$ \\
\hline Amikacin and cloxacillin & 04 & $2.4 \%$ \\
\hline Ceftriaxone and gentamicin & 02 & $1.2 \%$ \\
\hline Meropenem and vancomycin & 01 & $0.6 \%$ \\
\hline $\begin{array}{l}\text { Ceftriaxone, ampicillin and } \\
\text { gentamicin }\end{array}$ & 03 & $1.8 \%$ \\
\hline Ceftiaxone, amikacin and cloxacillin & 01 & $0.6 \%$ \\
\hline
\end{tabular}


Table 5: Frequency of antibiotic/combination of antibiotics prescribed for LRTI in >6 months-2 years of age.

\begin{tabular}{|lll|}
\hline $\begin{array}{l}\text { Antimicrobial / combination } \\
\text { of antimicrobials }\end{array}$ & $\begin{array}{l}\text { No. of } \\
\text { patients }\end{array}$ & $\%$ \\
\hline Ceftriaxone & 19 & $20.6 \%$ \\
\hline Ampicillin & 04 & $4.3 \%$ \\
\hline $\begin{array}{l}\text { Ampicillin and } \\
\text { chloramphenicol }\end{array}$ & 20 & $21.7 \%$ \\
\hline Ceftriaxone and cloxacillin & 11 & $11.9 \%$ \\
\hline Ampicillin and gentamicin & 10 & $10.8 \%$ \\
\hline Ceftriaxone and amikacin & 06 & $6.5 \%$ \\
\hline Ampicillin and chloromycetin & 05 & $5.4 \%$ \\
\hline Ceftriaxone and ampicillin & 04 & $4.3 \%$ \\
\hline $\begin{array}{l}\text { Ceftriaxone and } \\
\text { chloramphenicol }\end{array}$ & 04 & $4.3 \%$ \\
\hline Ceftriaxone and vancomycin & 02 & $2.1 \%$ \\
\hline $\begin{array}{l}\text { Crystalline penicillin and } \\
\text { chloramphenicol }\end{array}$ & 02 & $2.1 \%$ \\
\hline Meropenem and amikacin & 01 & $1.08 \%$ \\
\hline $\begin{array}{l}\text { Ceftriaxone, ampicillin and } \\
\text { gentamicin }\end{array}$ & 04 & $4.3 \%$ \\
\hline
\end{tabular}

Table 6: Frequency of antibiotic /combination of antibiotics prescribed for LRTI in > 2-12 years of age.

\begin{tabular}{|lll|}
\hline $\begin{array}{l}\text { Antimicrobial/combination } \\
\text { of antimicrobials }\end{array}$ & $\begin{array}{l}\text { No. of } \\
\text { patients }\end{array}$ & $\%$ \\
\hline Ceftriaxone & 06 & $13.6 \%$ \\
\hline Ceftriaxone and cloxacillin & 11 & $25 \%$ \\
\hline $\begin{array}{l}\text { Ampicillin and } \\
\text { chloramphenicol }\end{array}$ & 07 & $15.9 \%$ \\
\hline $\begin{array}{l}\text { Crystalline penicillin and } \\
\text { chloramphenicol }\end{array}$ & 06 & $13.6 \%$ \\
\hline Ceftriaxone and vancomycin & 04 & $9.09 \%$ \\
\hline Ampicillin and gentamicin & 04 & $9.09 \%$ \\
\hline Meropenem and vancomycin & 02 & $4.5 \%$ \\
\hline Meropenem and clindamycin & 01 & $2.2 \%$ \\
\hline $\begin{array}{l}\text { Ceftriaxone, cloxacillin and } \\
\text { amikacin }\end{array}$ & 03 & $6.8 \%$ \\
\hline
\end{tabular}

Table 7: Duration of stay per underlying infection in hospital.

\begin{tabular}{|ll|}
\hline Diagnosis & Duration of stay (days) \\
\hline Pneumonia & 6.6 \\
\hline WALRTI & 5.2 \\
\hline $\begin{array}{l}\text { Pleural effusion with } \\
\text { consolidation }\end{array}$ & 9.3 \\
\hline Post-measles pneumonia & 6 \\
\hline Empyema & 14.6 \\
\hline Average duration & 8.34 \\
\hline
\end{tabular}

In a total of 300 patients, $49(16.33 \%)$ patients developed adverse drug reactions while 251 subjects showed no adverse reaction to any drug.
In a total of 211 males, 32 male patients showed adverse drug reactions while out of 89 female patients, 17 showed ADRs (Table 8).

Table 8: Distribution of ADRs according to gender.

\begin{tabular}{|lllll|}
\hline Gender & $\begin{array}{l}\text { No. of } \\
\text { patients } \\
\text { studied }\end{array}$ & $\begin{array}{l}\text { ADRs } \\
\text { present }\end{array}$ & $\begin{array}{l}\text { ADRs } \\
\text { absent }\end{array}$ & $\%$ \\
\hline Male & 211 & 32 & 179 & $15.2 \%$ \\
\hline Female & 89 & 17 & 72 & $19.1 \%$ \\
\hline Total & 300 & 49 & 251 & $16.3 \%$ \\
\hline
\end{tabular}

It was also observed that patients in age group 2 months-6 months had maximum ADRs (17.68\%) while patients in age group $>2$ years-12 years had minimum ADRs (13.64\%) (Table 9).

Table 9: Distribution of ADRs in different age groups.

\begin{tabular}{|lllll|}
\hline Age group & $\begin{array}{l}\text { No. of } \\
\text { patients }\end{array}$ & $\begin{array}{l}\text { ADRs } \\
\text { present }\end{array}$ & $\begin{array}{l}\text { ADRs } \\
\text { absent }\end{array}$ & $\%$ \\
\hline 2-6 months & 164 & 29 & 135 & $17.6 \%$ \\
\hline $\begin{array}{l}\text { >6 months- } \\
\text { 2 years }\end{array}$ & 92 & 14 & 78 & $15.2 \%$ \\
\hline $\begin{array}{l}\text { > 2 years- } \\
\text { 2 years }\end{array}$ & 44 & 6 & 38 & $13.6 \%$ \\
\hline Total & 300 & 49 & 251 & $15.5 \%$ \\
\hline
\end{tabular}

In present study, out of 49 cases of ADRs, 10 cases ( 8 cases of diarrhoea and 1 case each of vomiting and constipation) were due to ceftriaxone alone, remaining 39 cases were due to combination of antibiotics. Besides ADRs of gastrointestinal system, skin rashes were observed in 4 cases due to combination of ceftriaxone with cloxacillin and ampicillin with gentamicin (Table 10).

Table 10: Number and percentage of subjects with different ADRs.

\begin{tabular}{|lll|}
\hline Adverse drug reaction & $\begin{array}{l}\text { No. of patients } \\
\text { with ADRs }\end{array}$ & $\%$ \\
\hline Diarrhoea & 36 & $73.4 \%$ \\
\hline Constipation & 04 & $8.2 \%$ \\
\hline Vomiting & 03 & $6.1 \%$ \\
\hline $\begin{array}{l}\text { Diarrhoea with } \\
\text { vomiting }\end{array}$ & 02 & $4.1 \%$ \\
\hline Skin rashes & 04 & $8.2 \%$ \\
\hline Total & 49 & $100 \%$ \\
\hline
\end{tabular}

Most common combination of antibiotics associated with maximum ADRs were ceftriaxone with amikacin, ampicillin with gentamicin and ampicillin with chloramphenicol (Table 11).

\section{DISCUSSION}

The prescription of antimicrobials in children is done by clinicians who might not be familiar with the rationality of 
drug choices and this may result in significant implications for the patient, legal and economic implications for the hospital, and medico-legal implications for the physician.

\section{Table 11: Type and number of ADRs associated with} different antibiotics.

\begin{tabular}{|lll|}
\hline \multirow{2}{*}{ Anti-microbial } & ADRs & $\begin{array}{l}\text { No. of } \\
\text { patients }\end{array}$ \\
\hline \multirow{3}{*}{ Ceftriaxone (i.v.) } & Diarrhoea & 08 \\
\cline { 2 - 3 } $\begin{array}{l}\text { Ceftriaxone (i.v.) with } \\
\text { cloxacillin (i.v.) }\end{array}$ & Vomiting & 01 \\
\cline { 2 - 3 } & Constipation & 01 \\
\cline { 2 - 3 } & Domiting & 02 \\
\hline Diarrhoea with & 01 \\
\hline $\begin{array}{l}\text { Ceftriaxone (i.v.) with } \\
\text { amikacin (i.v.) }\end{array}$ & Skin rashes & 02 \\
\hline $\begin{array}{l}\text { Ceftriaxone (i.v.) with } \\
\text { gentamicin (i.v.) }\end{array}$ & Diarrhoea & 10 \\
\hline $\begin{array}{l}\text { Ampicillin (i.v.) with } \\
\text { gentamicin (i.v.) }\end{array}$ & Diarrhoea & 02 \\
\hline $\begin{array}{l}\text { Ampicillin (i.v.) with } \\
\text { chloramphenicol (i.v.) }\end{array}$ & Diarrhoea & 07 \\
\hline $\begin{array}{l}\text { Meropenem (i.v.) with } \\
\text { clindamycin (oral) }\end{array}$ & Constipation & 01 \\
\hline
\end{tabular}

Previous surveys have demonstrated that in approximately half of hospitalized patients given antimicrobials there is no clear indication for its use or that the choice and duration of therapy is not the most appropriate for the patient's clinical condition. ${ }^{20}$ A study by WHO program for appropriate health care technology has shown a correlation between the occurrence of multi-resistant bacteria and antibiotic consumption pattern. ${ }^{21}$ Throughout the 1990 s, public health and professional organizations, including the Centre for Disease Control and Prevention (CDC), American Academy of Pediatrics, American Academy of Family Practice, American Society for Microbiology, and Alliance for the Prudent Use of Antibiotics undertook campaigns and interventions to promote appropriate antimicrobial use which is defined as use that maximizes therapeutic impact while minimizing toxicity and development of resistance. ${ }^{22}$

Detailed knowledge of antibiotic prescription pattern is important before policies and measures can be implemented. The present study was therefore undertaken in order to determine the prescribing pattern of antimicrobials in children and determine incidence and nature of adverse drug reactions so that clinicians can be familiar with the most common side effects of most frequently used antimicrobials. This will provide help to clinicians, pharmacologists, pharmaco-epidemiologists and pharmaco-economists in devising a comprehensive plan for better child care, resource management and adoption of safe and rational drug policies.
In present study, a total of 300 patients suffering from LRTI and hospitalized in pediatric ward were included. The results showed that $70.6 \%$ of cases were males and $54.6 \%$ of cases belonged to 2 months- 6 months age group. This provides the evidence that young male infants in developing countries are at significant health risk and hence clinicians, caretakers and health planners should adopt better strategies for these children. In present study the most frequent diagnosis of LRTI for which antibiotic drugs were prescribed, was pneumonia (62\%) followed by WALRTI $(28.67 \%)$, pleural effusion with consolidation (5\%), empyema $(2.33 \%)$ and post-measles bronchopneumonia $(2 \%)$. This study result was supported by an earlier study done by Bosu et al, which found that maximum number of children who received antimicrobial drugs were hospitalized for acute pneumonia. ${ }^{23}$ In present study, out of 300 patients, blood culture and sensitivity tests were done on $270(90 \%)$ patients out of which 28 $(10.37 \%)$ were culture positive and $242(89.63 \%)$ were culture negative. Out of 28 culture positive results, in 21 cultures, etiologic agent was streptococcus pneumoniae and in 7 cultures, etiological agent was staphylococcus aureus. In literature it is mentioned that blood cultures are positive in only $10 \%-20 \%$ of children with pneumococcal pneumonia. ${ }^{24}$ In this study, mostly empirical antibiotics were prescribed for clinical conditions before laboratory confirmation of microbial etiology. This has been documented as the leading cause of drug resistance.

The excessive use of injectables is common in many developing countries. In present study except for clindamycin, other antimicrobials were administered by injectable route in all patients included in the study. This provides evidence that clinicians might be overprescribing the injectable antibiotics, however individual case to case variations (severity of LRTI) should be taken into account.

In present study, $70.7 \%$ of hospitalized patients were prescribed at least two antibiotics which was different from the study conducted by Palikhe N, which showed use of single antibiotic more as compared to drug combination. ${ }^{25}$ This might be due to variation in selection of antimicrobials by physician or variable severity of underlying infection. Out of 300 hospitalized patients, it was observed that 71 children were given a single antibiotic, while 2 and 3 antimicrobials were prescribed to 212 and 17 patients respectively. A similar study done by Bosu et al, showed variation in the percentage of patients who were prescribed at least one antibiotic in different health centers. ${ }^{23}$ These results provide the evidence that use of antibiotic drug combinations far exceeds the single administration and this might be helpful for resource managers and health planners to ensure adequate drug supplies in tertiary care setup.

ADRs account for $2.9 \%-15.4 \%$ of all hospital admissions in US. According to Lazarou et al, 1998, more than 100,000 hospitalized patients in USA die each year due to ADRs. ${ }^{26}$ Prospective pediatric drug surveillance studies performed in six different countries, with two each in Germany and France have shown ADR incidence $1.5 \%$ - 
$19.9 \%$ in hospitalized children. ${ }^{20}$ There are only a few such studies in India, so present study was undertaken in order to determine the incidence of ADRs in children. Out of 300 patients in present study, ADRs occurred in 49 (16.3\%) patients. In present study, it was observed that age group 2 months -6 months had highest percentage cases of ADRs i.e. $29(17.68 \%)$ while age group 2 years-12 years had minimum number of ADR patients which was 6 (13.64\%). This provides evidence that young infants are the most vulnerable group and extra efforts (clinical, social and economic) should be undertaken for care of these children. In the present study highest percentage of adverse reactions were related to gastrointestinal system and diarrhoea was most common ADR in $82.2 \%$ of $91.8 \%$ gastrointestinalrelated ADRs followed by constipation $8.9 \%$, vomiting $6.7 \%$, and diarrhoea with vomiting $4.4 \%$. Present study also revealed that largest percentage cases of diarrhoea were associated with combination of ceftriaxone and amikacin $(27.7 \%)$. These findings were similar to an earlier study conducted by Hoffman $\mathrm{T}$ et al, according to which non-clostridium difficile diarrhoea was commonly associated with ampicillin, amoxicillin-clavulanic acid, ceftriaxone, macrolides or trovafloxacin. ${ }^{27}$ Present study also showed that $8.2 \%$ of patients with ADR had skin rashes. In another study conducted by Clavenna $\mathrm{A}$ et al, skin and gastrointestinal tract were the organ systems most commonly involved, and antibiotics were the drugs most frequently associated with ADRs in children. ${ }^{17}$ These results provide evidence that clinicians should be aware of the most common ADRs caused by antibiotics and efforts should be made to use these drugs as rationally as possible. As per Naranjo ADR Probability Scale or WHO-UMC causality categories, 49 adverse drug reactions in this study were all 'possible' reactions because in 39 patients, ADRs were attributed to concurrent antimicrobials (combination of antimicrobials) and in all patients withdrawal (dechallenge) of drug was not done. All adverse events were of 'mild' severity since none resulted in any significant disability or required any additional management or prolongation of hospitalization.

The results of present study provided the evidence that age group 2-6 months male children are particularly susceptible to LRTI and develop maximum number of ADRs with combination of ceftriaxone and amikacin or ceftriaxone alone and hence, physicians should possess a clear understanding of the need of microbiological diagnosis(be judicious in use of empirical therapy), use of correct antibiotics (prescribing drug combinations rationally) and making good judgment in clinical situations which will result in decrease in incidence and severity of ADRs (knowledge of common ADRs) following the use of anti-microbial therapy.

\section{ACKNOWLEDGEMENTS}

Authors acknowledge the co-operation of resident doctors and Senior Physicians of Pharmacology and Pediatrics Department in the University College of Medical Sciences and G.T.B. hospital, New Delhi for their valuable support and guidance.

Funding: No funding sources

Conflict of interest: None declared

Ethical approval: The study was approved by the Institutional Ethics Committee

\section{REFERENCES}

1. Kumari Indira KS, Chandy SJ, Jeyaseelan L, Kumar R, Suresh S. Antimicrobial prescription patterns for common acute infections in some rural and urban health facilities of India. Indian J Med Res. 2008 Aug;128(2):165-71.

2. Graffelman AW, Neven AK, le Cessie S, Kroes AC, Springer MP, van den Broek PJ. Pathogens involved in lower respiratory tract infections in general practice. Br J Gen Pract. 2004 Jan 1;54(498):15-9.

3. Kelsey MC, Mitchell CA, Griffin M, Spencer RC, Emmerson AM. Prevalence of lower respiratory tract infections in hospitalized patients in the United Kingdom and Eire-results from the Second National Prevalence Survey. J Hospital Infect. 2000 Sep 1;46(1):12-22.

4. Black RE. Zinc deficiency, infectious disease and mortality in the developing world. J Nutr 2003;133:1485-9.

5. Smith KR, Samet JM, Romieu I, Bruce N. Indoor air pollution in developing countries and acute lower respiratory infections in children. Thorax. 2000 Jun 1;55(6):518-32.

6. Peng D, Zhao D, Liu J, Wang X, Yang K, Xicheng H, et al. Multipathogen infections in hospitalized children with acute respiratory infections. Virol J. 2009 Dec;6(1):155.

7. Rudan I, Tomaskovic L, Boschi-Pinto C, Campbell H. WHO Child Health Epidemiology Reference Group. Global estimates of the incidence of clinical pneumonia among children under five years of age. Bull World Health Organization. 2004;82:895-903.

8. Rosón B, Carratalà J, Dorca J, Casanova A, Manresa F, Gudiol F. Etiology, reasons for hospitalization, risk classes, and outcomes of community-acquired pneumonia in patients hospitalized on the basis of conventional admission criteria. Clin Infect Dis. 2001 Jul 15;33(2):158-65.

9. Hazir T, Nisar YB, Qazi SA, Khan SF, Raza M, Zameer $\mathrm{S}$, et al. Chest radiography in children aged 259 months diagnosed with non-severe pneumonia as defined by World Health Organization: descriptive multicentre study in Pakistan. BMJ. 2006 Sep 21;333(7569):629.

10. Fields E, Chard J, Murphy MS, Richardson M. Assessment and initial management of feverish illness in children younger than 5 years: summary of updated NICE guidance. BMJ. 2013 May 22;346:f2866.

11. Khaled LA, Ahmad F, Brogan T, Fearnley J, Graham J, MacLeod S, et al. Prescription medicine use by one 
million Canadian children. Paediatr Child Health. 2001 Dec 1;8(suppl_A):6A-56A.

12. Harris M, Clark J, Coote N, Fletcher P, Harnden A, McKean M, et al. On behalf of the British thoracic society standards of care committee guidelines for the management of community acquired pneumonia in children. Brit Thoracic Society. 2011;66:4-23.

13. Smart K, Lemay J, Kel JD. Antibiotic choices by pediatrics residents and recently graduated pediatricians for typical infectious disease problems in children. Paediatr Child Health. 2006;11:647-53.

14. da Cunha A, Amaral J, Silva MA. Inappropriate antibiotic prescription to children with acute respiratory infection in Brazil. Indian Pediatr. 2003 Jan;40:7-12.

15. Bharathiraja R, Sridharan S, Chelliah LR, Suresh S, Senguttuvan M. Factors affecting antibiotic prescribing pattern in pediatric practice. Indian $\mathrm{J}$ Pediatr. 2005 Oct 1;72(10):877-9.

16. Sahu SK, Satapathy DM, Sahu T, Tripathy RM, Das BC, Pradhan S. A study of acute respiratory tract infection cases admitted to a tertiary level health centre. Health Population Perspectives Issues. 2002;25:186-95.

17. Clavenna A, Bonati M. Adverse drug reactions in childhood: a review of prospective studies and safety alerts. Arch Dis Childhood. 2009 Jun 15.

18. WHO. The use of the WHO-UMC system for standardized case causality assessment. Geneva: World Health Organization. 2011. Available at: http://www.WHO-UMC.org. Accessed 13 April 2012.

19. Lei HS, Rahman AF, Haq AS. Adverse drug reaction reports in Malaysia: comparison of causality assessments. Malays J Pharm Sci. 2007;5:7-17.

20. Javato-Laxer M, Navarro E, Littana R. Antimicrobial patterns in hospitals: determinants and proposed interventions. Philipp. J Microbiol Infect Dis. 1989;18:41-6.

21. Sjöqvist F. Drug safety in relation to efficacy: the view of a clinical pharmacologist. Pharmacol Toxicol. 2000 Jun;86:30-2.

22. McCaig LF, Besser RE, Hughes JM. Trends in antimicrobial prescribing rates for children and adolescents. JAMA. 2002 Jun 19;287(23):3096-102.

23. Bosu WK, Ofori-Adjei D. Survey of antibiotic prescribing pattern in government health facilities of the Wassa west district of Ghana. East African Med J. 1997 Mar;74(3):138-42.

24. Sectish TC, Prober CG. Pneumonia. Kliegman RM, Santon BF, St. Geme JW, Schor NF, Behrman RE. In: Nelson Textbook of Pediatrics, 19th ed. Elsevier Philadelphia PA; 2011:1432-35.

25. Palikhe N. Prescribing pattern of antibiotics in pediatric hospital of Kathmandu Valley. J Nepal Health Res Council. 2004;2:31-6.

26. Lazarou J, Pomeranz BH, Corey PN. Incidence of adverse drug reactions in hospitalized patients: a metaanalysis of prospective studies. JAMA. 1998 Apr 15;279(15):1200-5.

27. Hoffman-Terry M, Fraimow H, Fox T, Swift B, Wolf J. Adverse effects of outpatient parenteral antibiotic therapy. Am J Med. 1999 Jan 1;106(1):44-9.

Cite this article as: Arora T, Kadali RP, Chandane RD, Gautam G. Prescribing pattern of antimicrobials and adverse drug reactions in children suffering from lower respiratory tract infection in tertiary care hospital. Int J Basic Clin Pharmacol 2018;7:2240-6. 